\title{
Impeachment at States' Level in Nigeria: Osun State as a Case Study
}

\author{
Fatai Ayisa Olasupo \\ Department of Local Government Studies, Faculty of Administration, Obafemi Awolowo University, Ile-Ife, \\ Nigeria \\ Email: faolasupo@yahoo.com
}

Received 15 January 2015; accepted 26 February 2015; published 28 February 2015

Copyright (C) 2015 by author and Scientific Research Publishing Inc.

This work is licensed under the Creative Commons Attribution International License (CC BY).

http://creativecommons.org/licenses/by/4.0/

(c) (i) Open Access

\section{Abstract}

As a three-tier government that Nigeria is, three legislatures exist and all of them have impeachment powers that have often been grossly abused: The National Assembly, the States Assemblies and the Local Government Legislative Councils. A close study of their activities, regarding impeachment duties, showed a consistent power struggle between chief executives and their deputies. This was the case between Chief Adebisi Akande and Otunba Iyiola Omisore; Governor and Deputy Governor of Osun-State respectively. It was interesting to note that this power struggle did not exclude the then speaker of the State House of Assembly, Dr. Mojeed Alabi. Chief Bisi Akande, Otunbalyiola Omisore and Dr. Mojeed Alabi deployed all necessary powers and influences within and without their respective corridors of powers to achieve their inordinate ambitions. In the titanic sweepstake, extraneous actors such as party leaders, presidency, inspector general of the police, Afenifere (a yorubal socio-cultural group) and traditional rulers were not left out of the crisis that led to the impeachment of the first Deputy Governor of Osun-State in the Fourth Republic, Otunbalyiola Omisore and the subsequent assassinations of Hon Odunayo Olagbaju the then Osun State House of Assembly member and, the Federal Attorney-General and Minister of Justice, Chief Bola Ige, who was also deputy leader of Afenifere. Party leaders refer to leadership of the various political parties, especially the ruling ones at the local, state and federal levels. The following officials: party chairman, zonal chairman, state chairman, local chairman and their secretaries are very critical in the running of their various political parties at all the levels of government. Specifically, in the case of Alliance for Democracy (AD), the national leaders of the party that intervened in the crisis that rocked Osun-State between 1999 and 2003 included: the leader of Afenifere, Pa (Senator) Abraham Adesanya; Deputy leader of Afenifere and Honourable Minister of Justice and Attorney-General of the Federation, Chief Bola Ige; Senator A. A. Abdulkadir, national chairman of Alliance for Democracy; Pa Archdeacon Emmanuel Alayande; Justice Adewale Thomson; and All the AD Governors (Olasupo, 2014). Although attempts were made to impeach the then governor and even the speaker, both failed except that of the deputy governor, Otunbalyiola Omisore. Why did the other two impeachments failed and that of the Deputy Governor who was from a 
different political party, Peoples Democratic Party (PDP), succeeded? This is a big question. The interplay of how these took place is the concern of this paper.

\title{
Keywords
}

\author{
Nigeria, Osun-State, Legislature, Impeachment and Party Leaders
}

\section{Introduction}

Of all the impeachment sagas in Nigeria between 1999 and 2003, the most dramatic, brutal, violent and bloody was that of Osun State. It led to hacking to death of prominent citizens of the state: Chief Bola Ige, Federal Attorney-General and Minister of Justice; and Hon Odunayo Olagbaju, a prominent member of Osun-State House of Assembly. Both carnages were impeachment related in Osun State of Nigeria. One of the important factors that led to series of impeachments at all levels of government in Nigeria in the fourth republic was the issue of signing of agreement or deal between the political aspirants and the so-called kingmakers. At the federal level, there was one between Chief Olusegun Obasanjo and the northern power brokers. As a matter of fact, when Chief Obasanjo became Head of State, all ministerial aspirants were made to sign an oath of non-betrayal. States were not left out of this "innovation" of securing the loyalty of aspirants to political offices through oath of secrecy. In the case of Osun-State, there was no evidence of oath taking or signed agreement but there was definitely unwritten agreement between Governor Akande and the Deputy Governor, Otunba Omisore.

An attempt to dishonour the said gentleman ship agreement led to suspicion, intrigues, impeachments and counter impeachments and ultimately outbreak of political violence. As the speaker of the House of Assembly in Osun-State noted, irreparable crack in the relationship between the governor and his deputy ensued but he also exploited this to explore the opportunity and the possibility of becoming deputy governor in the first instance, and governor ultimately. It backfired and he was also almost impeached too.

On one hand, the concern of this paper, relying on secondary sources, is to examine the interplay of these actors-Chief Bisi Akande, Otunba Iyiola Omisore and Dr. Mojeed Alabi-governor, deputy governor and speaker respectively in trying to impeach one another using the impeachment clause in the constitution. On the other hand, this will be counter balanced by primary sources and thus see their areas of agreements and disagreements with regard to impeachments as they interplay in Osun-State during the second republic.

\section{Impeachment Procedures}

\section{Governor or Deputy Governor}

Impeachment: according to Mike Ikhariale, impeachment “denotes a constitutional process designed to remove a president who has been found guilty of provable acts which, in the thinking of the legislators, amounted to "gross misconduct" (Ikhariale, 2002). Furthermore, Pini Jason, in a book: Power of Congress published by the Congressional Quarterly Inc; described impeachment as "perhaps the most awesome though the least used power of Congress". "The publication went further to describe impeachment as "a political action, couched in legal terminology, directed against a ranking official of the federal government”. In the United States, the House of Representative is the prosecutor. The Senate chamber is the courtroom; and the Senate is the judge and jury, said the book. The final penalty is removal from office and disqualification from further office. There is no appeal! (Jason, 2006). "In England”, as Azinge puts it, "Parliament saw impeachment as a powerful weapon of fighting the Lords and the Executives. It was a means of checking the excesses or despotism from those quarters" (Azinge, 2002). Since Nigeria adopted parliamentary system of government in the first republic and is now operating presidential system of government, all the constitutions within these periods made provision for impeachment clauses that have so far applied only at local and state levels.

Impeachment procedures need elaboration and illumination because most of the impeachment frauds in Nigeria are woven around them. The processes that constitutionally have to be followed in toeing impeachment procedures are so cumbersome that they may take not less than three months before a chief executive is successfully removed. Chief Executives at all the levels of government in Nigeria include the President/Vice-President, 
State Governor/Deputy-Governor and Chairman/Vice-Chairman at the local level (Omololu, 2007). However, what operates today is removing chief executive in less than a week's time. In some places, Speakers of the House of Assembly are removed within a day. Or how does one explain the case of Imo State House of Assembly that produced three Speakers in less than a fortnight! The first Speaker of the House that was validly elected was Noel Aguocha Chukwukadibia. Upon his removal as Speaker, his Deputy, Ernest Ibejiako stepped in. In less than a week "reign" of Noel, another Speaker, Nnaemeka Maduagu stepped in (Aja, 2001). This is a classic example of abuse of due process. There are many of such abuses in the impeachment gale that is currently rocking every level of governments in Nigeria.

Now, what are the constitutionally stipulated procedures that Legislatures must follow when embarking on impeachment of Chief executives or leaderships of the legislatures at state level? The 1999 Constitution is clear on how a Governor or the Deputy of a state may be removed from office if found "guilty of gross misconduct in the performance of the functions of his office" (S. 188(1)). This section provides that "a notice of any allegation in writing" shall be "signed by not less than one-third of the members of the House of the Assembly" detailing the specific particulars of such "gross misconduct" with the accused Governor or Deputy Governor having the opportunity to respond thereto. The notice is presented to the Speaker. This is stage one.

Stage two is that the Speaker of the House of Assembly shall, within seven days of the receipt of the notice, cause a copy of the notice to be served on the holder of the office and on each member of the House of Assembly, and shall also cause any statement made in reply to the allegation by the holder of the office, to be served on each member of the House of Assembly.

The third stage is that within 14 days of the presentation of the notice to the speaker of the House of Assembly, the House shall resolve by way of motion whether or not to investigate the said allegations.

The fourth stage is that, according to subsection (4) thereof, "A motion of the House of Assembly that the allegation be investigated shall not be declared as having been passed unless it is supported by the votes of not less than two-thirds majority of all the members of the House of Assembly” (Iyinbo, 2007).

The fifth one is that the Speaker of the House shall, within seven days of the passing of the motion (supported by two-thirds majority of all the members of the House of Assembly) state that the allegation be investigated, caused the allegation to be investigated by a Committee of seven persons.

Sixth, that the seven persons, approve by the House of Assembly, are in the opinion of the Speaker, of "high integrity, not being members of any public service, legislative house or political party" to conduct the investigation.

Seventh, that the Governor or Deputy Governor shall have the right to defend himself in person and be represented by lawyers of his own choice before the Investigation Committee.

Eight, that the Investigations Committee shall: 1) have such powers and exercise its functions in accordance with such procedures as may be prescribed by the House of Assembly; and 2) report its findings to the House of Assembly within three months.

Nine that the impeachment proceedings shall cease if the Investigations Committee reports to the House of Assembly that the allegation has not been proved.

Ten, that if the Investigations Committee reports that the allegation against the Governor or Deputy Governor has been proved, the House shall, within fourteen days of the receipt of the Report, consider the Report (Akinsanya, 2005).

Eleventh, that the Governor or Deputy Governor stands automatically removed from office the very day that the Report of the Investigations Committee is adopted by a resolution of the House of Assembly supported by not less than two-thirds majority of all its members.

\section{Governor}

Attempted impeachment of Governor Akande was aptly likened, by most commentators over the Osun State crisis, to that of Chief S.L Akintola. As that of Chief S. L. Akintola tore the entire Yoruba land into two, the consequence of which still lingers today, that of Chief Bisi Akande would almost have been a similitude of that, had the impeachment succeeded. This is because the factors at play in the case of Chief Akintola and Awolowo were similar to the ones at play in the case of Chief Bisi Akande and Otunba Iyiola Omisore. The factors in the case of Chief Akintola were Chief Obafemi Awolowo, as Federal leader of opposition and Action Group Party leader; Sir Adesoji Aderemi, the Ooni of Ife and Governor of Western Nigeria; Chief Remi Fani Kayode, Deputy Pre- 
mier under Chief S.L. Akintola; Alhaji Adegbenro; the Northern People’s Congress (NPC) and the Federal Government. In the case of Chief Bisi Akande, the factors that would have defined another round of civil war, perhaps, are Chief Abraham Adesanya, the leader of Afenifere; Chief Bola Ige, the Deputy leader of Afenifere and the Federal Attorney-General and Minister of Justice; Otunba Iyiola Omisore, the Deputy Governor; The Ooni of Ife, Oba Okunade Sijuwade, though not a Governor in the mould of Sir Aderemi, his commands of influence in local and national politics are overwhelmingly intimidating and parallel to that of Sir Adesoji Aderemi. (Chief Funmilola Olorunishola, press secretary to the Ooni of Ife, described it as "huge and deep contacts in the corridor of powers over the years) (Olorunnisola, 2010). Other stakeholders include the PDP, Federal Government and the Alliance for Democracy Governors in the South West.

Right from the onset, it was clear the $\mathrm{AD}$ and Afenifere leaders were incapable of dousing the ambition of the two power strugglers in Osun State government, given the fact that these leaders were also embroiled in power struggle between Chief Abraham Adesanya and Chief Bola Ige.

Power Struggle is a situation where two people or groups are trying to become the more or the most powerful. It could happen in a company where for example some members of the board of directors form a group and want their preferred choice to become CEO or whatever and a rival group want their preferred candidate. It recently happened in Zimbabwe; following a power-sharing deal between Robert Mugabe as President and Morgan Tsvangiraias Prime Minister. Butthere still exist major disagreements and power-struggle between the two about who will have control over important areas such as the police and military (because whoever has control of these is likely to be the most powerful (http://answers.yahoo.com/question/index?qid=20090308070903AAcWBT3). In the same vein the power struggle between the Governor of Osun State and his Deputy centred on who controlled the House of Assembly, for whoever controlled it out of the two would have been the most powerful.

Lined up behind Chief Abraham Adesanya were other Afenifere leaders such as Chief Ayo Adebanjo, Chief OlanihunAjayi and Chief OluFalae among others. Behind Chief Bola Ige were Chief Ayo Fasanmi and Arch Deacon Emmanuel Alayande, in the main. The cause of the power struggle was over whom to become the presidential candidate of Alliance for Democracy in the 1999 Presidential election. This power struggle led to separation of Afenifere from Alliance for Democracy. It also led to Chief Bola Ige deciding to serve in the PDP Federal Government against the wish of his colleagues in Afenifere. Thus, while Chief Adesanya group was in control of Afenifere, Chief Bola Ige group was in control of AD as well as most of AD Governors. Under this scenario, it was doubtful any meaningful intervention could be affected in the rift between Governor Bisi Akande and Otunba Iyiola Omisore who had positioned themselves along this cleavage.

Nevertheless, concerted attempts were made by these ideologically polarised groups to undermine each other. Chief Bisi Akande, as the first Governor of Osun State in the fourth republic, contrary to expectation, was first to be threatened with impeachment. It was not immediately clear who was behind the threat. The Deputy Governor, Otunba Iyiola Omisore, was the one supporters of Chief Akande however alleged to be behind the plot (Ajayi, 2001). But the Deputy Governor had no executive power to affect this although he had money. The most other likely person to have done this was the Speaker, Dr Alabi. Although he had the power as third citizen in the state with awesome legislative power, he was not rich enough to embark on such elaborate plot; although he was alleged to be covertly lending support to the plotters. In fact, in one of their planning activities, outside the legislative chamber in faraway Hilton Hotel in Ile-Ife, he was said to "be very careful not to be seen with them" (plotters), "he was in a room upstairs, but was not physically present with them". He was later said to have met with two of the conspirators, right inside the hotel (Cover, 2002a, 2002b). The Speaker however flatly rejected this assertion in my discussion with him. We shall come to this in details later.

\section{Impeachment Notice to the Governor Akande}

In any case, in November 2000, a near consensus of the 26 members of the State House of Assembly served impeachment notice to Governor Bisi Akande, listing 22 impeachable offences (Icheku, 2002). The detailed particulars of the allegations are as follows:

1) That the said Chief Adebisi Bamdele Akande has committed grave violations of the provision of section 100(4) of the Constitution by his failure, refusal, or neglect to signify that he assents or that he withhold assent within the 30 days required by the Constitution when the Osun State House of Assembly (Self-Accounting) Bill was presented to him for his signature.

2) That the said Chief AdeBisi Akande violated the provisions of section 5(2) and section 100(5) of the Con- 
stitution by his refusal, failure or neglect to implement the Osun State House of Assembly (Self-Accounting) Law passed into Law as required by the Constitution on $8^{\text {th }}$ February 2000. The bill was again passed by the application of S. 100(5) of the Constitution on $1^{\text {st }}$ June, 2000 after the House had waited for almost four months for the Governor to indicate that he gives or withholds assent.

3) That the said Chief Akande is in continuing breach of 10(4) of the Constitution by refusing to signify the he assents or withholds assent within 30 days as required by Law to the bill titled Permanent Board of Enquiry (Dissolution and Prohibition etc.) bill passed into Law by the House of Assembly on $4^{\text {th }}$ May, 2000 and issued for his signature.

4) That the said Chief A.B. Akande has continued to gravely violate the provisions of section 287(3) of the Constitution. That he failed, refused or neglected to implement the Osun State House of Assembly (SelfAccounting) Law after the suit against the implementation of the said law was dismissed by the High Court of Justice, Osogbo notwithstanding the non-existence of a subsisting appeal or order of court staying the execution of the said judgement.

5) That the said Chief A.B. Akande violates the provisions of section 5(a) (b); 120 (4) and 121 (3) of the 1999 Constitution of the Federal Republic of Nigeria by his failure, refusal and/or neglected to implement the appropriation Law 2000 in a manner prescribed by the House of Assembly (Notice of allegation).

\section{Further Particulars of the Impeachment Notice}

a) Failure to produce and make available to the House for the purpose of monitoring the implementation of the Appropriation Laws, the details of the budget Estimates as passed by the House of Assembly;

b) Refusal to make money available to the House as requested to produce the detailed Budget Estimates as passed by the House of Assembly for purpose of monitoring the implementation of the Budget;

c) Diversion of the money meant for capital projects in the House to for payment of some Contractors for job done before the inauguration of the House and for which no provision was made by the House in the Appropriation Law 2000; and payment of millions of naira on contract under probe by the House:

6) That the said Chief A.B. Akande violated the provision of section 125(2) When he purportedly acted on the interim audit reports of the Auditor-General (Which was marked for his information only) without allowing the House of Assembly to perform its Constitutional Duty under S. 125(2) of the Constitution to consider the report.

7) That Governor Chief A.B Akande also violated section 125(2) and (4) of the Constitution when he usurped the powers of the Auditor-General and the House of Assembly under the Constitution set and inauguratethrough the Commissioner for Finance and a so-called Permanent Board of Enquiry despite several and repeated resolutions of the House warning him of the consequences of this unjustifiable interference in the function of the Auditor-General and the House of Assembly.

8) That Chief A.B. Akande flagrantly breached the provision of the Edict establishing the Osun State Agricultural Development program (OSSADEP) when he purportedly took some disciplinary actions of suspending some officers, freezing the accounts of the said OSSADEP in grave violation of the relevant section of the Edict, which is an existing law.

9) That the said Chief A.B. Akande flagrantly incurred unlawful and unauthorised expenditure of public fund on the operation of the Permanent Board of Enquiry notwithstanding the prohibition of such expenditure by the resolution of the House dated $18^{\text {th }}$ April, 2000 and the passing of the Permanent Board of Inquiry (Dissolution and prohibition, etc.) Bill into law $4^{\text {th }}$ May, 2000.

10) The said Chief A.B Akande has demonstrated gross incompetence and lack of crisis-management ability in the administration of the state particularly in the resolution of the lingering industrial crisis in the public sector of Osun State leading to several weeks of avoidable strike action by workers aggravated by the unguided and often combative public posturing of the Governor on matters bordering on the welfare of the workers and the people of Osun State. This has negatively affected the image of members of the government (both legislative and executive) and affected negatively the public image of the ruling party—-the Alliance for Democracy—and this constitute a breach of section 14(2) (b) and section 13 of the Constitution. The House of the Assembly is always on the receiving end of the attendant demonstrations leading to kidnapping on two separate occasions of Honourable Members of the House including the Deputy Speaker and the Chief Whip.

11) That the said Chief Akande has wilfully and persistently undermine the integrity of the Osun State House of Assembly and the Honourable Members through deliberate underfunding and stifling of the House of Assem- 
bly by refusing to implement the budget of the House and/or implement the self-Accounting Law, a situation that has prevented the smooth administration of the House of Assembly and in the proper discharge of its functions as enjoined by section 4(7) of the Constitution, and his refusal to make available to the House Committee investigating the Past Military Administrators of billions of Naira belonging to the state which the Governor claimed at several forumsthat he had information on. Also, the Secretary to the State Government by a letter dated $11^{\text {th }}$ August, 1999, chided the House for inviting the Permanent Service Matter to appear on the floor of the House to discuss the issue relating to former Directors General (already retired) who were still in the service of Osun-State Government as Permanent Secretaries. The House condemned the said letter as derogatory to the House.

12) The said Chief A.B. Akande violated existing Civil Service rules and procedure when, without any criteria that are open and transparent, no less than one hundred and twenty-nine staffer of the Osun State Broadcasting corporation were retrenched.

13) The said Chief Bisi Akande wilfully and persistently refused to implement several resolution of the House which he has often described as "mere advice". These include:

i) Resolutions dated $21^{\text {st }}$ July, 1999 and $24^{\text {th }}$ August, 1999 calling on the Governor to release the Government White Paper on the Judicial Panel of Inquiry on the recovery of public property (a.ka. Aremu Panel). Yet the Governor has embarked on selective implementation of the same report without transparency and openness.

ii) Resolution dated $14^{\text {th }}$ July, 1999, the composition on Local Government Council which the Governor premptively undermined by issuing the Local Government Law (modification order) 1999, which violated sections 4(6), 7 and 100(2) of the Constitution.

iii) Resolution dated $21^{\text {st }}$ July, 1999 and several others requiring the Governor to make available to the House the monthly statement of receipts and expenditure of government since June 1, 1999 to enable the House perform its function of controlling public funds as enshrined in the Constitution.

iv) Resolution dated $21^{\text {st }}$ July, 1999, mandating the Governor to conduct an audit of all government properties especially heavy duty equipment, vehicles and quarters with a view to knowing the use to which such properties were being put.

v) Resolution dated $21^{\text {st }}$ June, 2000 asking the Governor to resume negotiation with various public sector workers' unions on the minimum wage crisis in order to avert another round of strike actions which was due to begin on the $6^{\text {th }}$ day of July, 2000 in order not to continue to paralyse economic activities of the generality of the people and/or endanger the educational advancement of the pupils of Osun State who had been out of school for the greater proportion of the academic year.

vi) Several resolution of the House requesting the Governor to remove or redeploy as may be appropriate Chief Lere Adebayo as the Honourable Commissioner in the State Ministry of Finance and Economic Development due to the persistence refusal of the said Commissioner to give effect to several resolutions of the House and for the gross incompetence displayed by the said Commissioner in the discharge of the duties of his office as well as incurring or causing the Governor to incur extra-budgetary spending. All these have caused disaffection within the Government.

To ensure no betrayal, members of the House, having passed the impeachment notice, were said to have taken "oath amongst them pledging to implement the impeachment notice without fail" (Notice of allegation). Although the House is made up of 26 members, only twenty (21) signed the impeachment notice. Those who signed included: Hon. Odunayo, Olagbaju, Hon. Barrister Bello Adejare, Hon. Dr. BabayomiTaiwo, Hon. Tewogbade A. Ayobami, Hon. Akinpelu Sunday, Hon. T.A Awotunde, Hon. AzeezPopoola, Hon. T AyofeAdisa, Hon. TaiwoOlajireAlawode, Hon B.O Hassan, Hon. J.O. Oyediran, Hon. Akindiya, Hon. Barrister Femi Popoola, Ola Gbotoso, Hon. MonrufudeenLawal, Hon. Akin Awoniyi, Hon J. A. Ajibode, Hon (Mrs.) O.O. Tejuosho, Hon. Komolafe B.O., Hon. Johnson Ojo and Hon. Fakayode (Notice of allegation).

It is important at this point to consider the role of Minority Leader, Hon. Barrister Adejare Bello in this power struggle, equation and the impeachment saga. Apart from being signatory to the impeachment notice, he was the second person to append his signature after Hon. Odunayo Olagbaju. Other than these, there was little or no overt or covert role of the Minority leader, either as masquerade behind the plot or one of the prime movers of it. However, one can guess that as a loyal party man, the position of the State's PDP Party leader in the internal crisis of $\mathrm{AD}$ was enough for him to go along the direction of the majority of the House members wanting impeachment of the Governor. The Party leader of the PDP in the State, Alhaji Fatai Akinbade, had, at the peak of the crisis in the state, called for the resignation of both Governor and his Deputy. Since the PDP, as the major 
opposition party in the state at that time was likely to ascend power at the collapse of the ruling party, whatever a loyal rival party man could do to bring down the ruling party will be pursued? For, as the Minority leader, if his party ascended power, he was most likely to become the Speaker. He did become one when the ruling party, AD, lost the State to PDP in the 2003 general election. So, it is safe to infer that the Minority leader, Hon. Adejare Bello, was also embroiled in the power struggle in the state at that time though tangentially. The roles of extraneous factors in this impeachment sage are also worth noting.

Extraneous factors that intervened in the impeachment crisis in Osun-State included State branch of Nigerian Union of Teacher, Chief Gani Fawehinmi, Alliance for Democracy AD, Afenifere, Yoruba Council of Elders (YCE) and the Delta State House of Assembly. While NUT and Chief Gani Fawehinmi sided with the Legislators in their move to impeach the Governor, the AD, Afenifere and YCE sided with the Governor, pleading with the rebellious Legislators to withdraw their impeachment motion. Specifically, in respect of the impeachment notice served the Governor, the House received emissaries from the following personalities: i) Ooni of Ife, Oba Okunade Sijuwade, ii) Pa Abraham Adesanya, iii) Yoruba Council of Elders, iv) Governor Niyi Adebayo of Ekiti State, v) Dr. Akin Onigbinde and others” (Federal Republic of Nigeria, 2000). Reasons why NUT backed the legislators were that "The name of our state has been dragged in the mud as our Governor always runs the state like a personal establishment. His highhandedness, obstinacy, rapacity, and indifference to the feelings of the masses make Osun State to be a laughing stock among the comity of states”. Chief GaniFawehinmi, on the other hand, wanted the Assembly to impeach the Governor over his non-performance (Federal Republic of Nigeria, 2000).

In any case, in point by point rebuttal, Governor Akande who received the impeachment notice through informal means rejected it although reacted to it. According to the Governor: "I have just managed to have a photocopy of the notice of the allegation against me from one of the members of the House of Assembly and I feel bold to reply as follows". Contrary to the Governor's claim, the House of the Assembly formally sent this notice of impeachment to him but the Governor deliberately avoided receiving it. Any way, he got a copy of the notice and replied the House of Assembly on the $8^{\text {th }}$ of November, 2000. Shortly after this, the Governor sent a caricature of US SEALs to obstruct the House process. According to reports, the Governor's “ADC and chief security officer” to him, "DSP A. A Adegoke and ASP Banjo Feitimi respectively led combat ready policemen to storm the House". The Speaker of the House was said to be one of those manhandled by the police. He was said to have collapsed as a result of this. My interaction with Speaker over this however proves to be an inaccurate press account. According to him (the Speaker) not many people knew that the Speaker's chamber in the House is designed in such a way that there are other outlets apart from the ones known to every member of the House; and only he alone had key to this ones. On that day of yore, when he sensed danger, he escaped through one of these inbuilt escape routes. As disloyal House members were visited with brimstone and fire, the anti-impeachment supporters-five in all-were said to have been rewarded with the sum of \#6.5 million naira for their loyalties to the Governor. On the $9^{\text {th }}$ of November, 2000, Delta State House of Assembly was one of the first extraneous factors that reacted to the coercive action of the Osun State Governor against the Osun State House of Assembly. After due deliberation, Delta State House of Assembly passed the following Resolution:

"Resolved, that this Honourable House condemns, in its entirety, the actions of the Osun State Police Command and the Governor of Osun State in the recent disgraceful invasion of the Osun State House of Assembly” (Okenyi, 2000).

Under the administration of another party in the state between 2003 and 2011, another impeachment process brewed. Again, the former Deputy Governor under AD administration, Chief and now Senator Iyiola Omisore, now a PDP member and Senator, was also the dramatic personae. The PDP Governor, Olagunsoye Oyinlola and his party PDP, like AD Governor Akande, had its own internal and external crisis as well. But the magnitude and intensity of his was incomparable to the previous to that of former Governor Akande. Internally, there were series of clashes within the administration of Governor Oyinlola: one, those between Governor Oyinlola and Senator Iyiola Omisore over broken promises and accord entered into before Prince Oyinlola ascended office. Two, there were series of internal PDP debate over the role of Otunba Iyiola Omisore's role in death of Attorney General of the federation and Minister of Justice who is an indigene of Osun-State, Chief Bola. Three, the was intense debate among the PDP bigwigs on whether Governor Oyinlola should be in government till 2011 and fourthly, the meddlesomeness of former Governor Isiaka Adeleke in the PDP politics in particular and Osun State in general (The Guardian, 2005). All of these led Speaker Adejare Bello to conclude that power struggle 
existed in the state between Governor Oyinlola and Senator Omisore. On one hand, and the alleged President Obasanjo's 3rd term agenda on the other (Daily Independence, 2005). In spite of all these, the crisis or clashes never degenerated to the point of impeachment of either the Governor or the Deputy, which is an indicator of existence of good crisis management mechanism within PDP.

However, had there not been judicial intervention that restored the mandate of Rauf Aregbesola, ACN gubernatorial candidate, as the legitimate winner of 2007 Osun State governorship election, another round of bloody crisis in Osun State would have ensued. The power struggle for the gubernatorial candidate of PDP in Osun State during the 2011 general election was so fierce and inordinate that aspirants spared nothing at enmeshing His Imperial Majesty, Oba Okunade Sijuwade, in an attempt to secure his support for their respective blind ambitions. Between Senator Iyiola Omisore, Fatai Akinbade and Peter power, among others, there was a serious mudslinging and deadly campaign to outdo one another with concomitant arms build-up.

\section{Deputy Governor}

Less than a year into the administration of Chiefs Akande and Otunba Omisore, signs had begun to show that doom was lying ahead of not just the two helms men in Osun state but also for their party, Alliance for Democracy (AD). An unwritten accord between the Governor and his Deputy, according to press report, was that the Governor would spend a term and the Deputy would complete the second one. This was based on the fact that the campaign finances and the running of the party's activities in the state (Osun) were borne by the Deputy Gubernatorial candidate. Even if this were not the case, the typical Nigerian political environment would have still driven wedge between the two of them.

Major cause of friction between the Governors and their Deputies in Nigeria today is lack of subordination on one hand, and lack of constitutional roles for them (Deputy Governors) on the other. More importantly is the refusal of the Governors to delegate lucrative responsibilities to their Deputies for fear they might use them to garner political influence and therefore constitute threats to them. Under the current constitution, the status of Deputy Governors, as Chukwuemeka Ezeife, who was also a former governor, puts it, is "spare-tyres" (Adeyemo, 2002). But the new Imo state Governor, OwelleOkorocha, appears to have found solution to this. He has made his Deputy, Engineer Ebere Udeagu, commissioner for works in the state.

At any rate, when signs began to get clearer that Governor Akande might not honour the gentleman ship agreement between him and his Deputy, and this was further reinforced by Chief Bola Ige at a meeting in his home at EsaOke, relations between the two began to freeze, while suspicions, accusations and counter-accusations set-in between the Governor and his Deputy. Concrete steps by the Deputy Governor to actualize his ambition of becoming Governor began to form thereafter (Babarinsa, 2002; Ajayi, 2001). When the Governor was travelling to Makkah to perform pilgrimage, rather than handing over power to the Deputy Governor, he handed it to the Secretary to the State Government, Mr. Sola Akinwumi. The Deputy Governor, Otunba Iyiola Omisore, reacted swiftly. He called a press conference at Ibadan where he decried the unconstitutionality of Governor Akande's action. He moved ahead to declare himself as Acting Governor (Ologbondiyan, 2002).

At the height of these, the State House of Assembly passed a motion asking the Deputy Governor to apologise to the Governor. Legislators loyal to the Deputy Governor reacted negatively to this. They interpreted the motion to mean serving impeachment notice to the Deputy Governor. Gun scare disrupted that sitting (Owolabi, 2002a, 2002b). The second time the law makers in Osun attempted to impeach him, the Deputy Governor was smarter enough to bring in thugs to invade the "house and chased out the Legislators" (Owolabi, 2002a, 2002b).

Before the situation degenerated to this level, extraneous factors had intervened. Afenifere socio-political group for instance set up a committee headed by Cornelius Adebayo to look into the feud. The committee recommended the resignation of the Deputy Governor, although this was never carried out (Owolabi, 2002a, 2002b). But by now, the Deputy Governor had also gotten the sympathies of the traditional ruler of his town and those of the rival political party, Peoples Democratic Party (PDP) that was suspected to be sponsoring the Deputy Governors' rebellion. In the Governor's security report, sent to President Olusegun Obasanjo, the Governor, Chief Bisi Akande, alleged that "the Ooni held a meeting where he invited the late Odunayo Olagbaju; Chief Audu Ogbe; Mr. Omibeku; Hon. Omidiora; Hon. Niyi Owulade and the Secretary to Ife Action Committee”. The points discussed at the meeting, in a nutshell, were the speculated alleged plans to remove Otunba Iyiola Omisore as the Deputy Governor of Osun State by the House of Assembly and remove the Ooni of Ife from the post of Chairman, Osun State Council of Obas and Chiefs, by the state government” (Ologbondiyan, 2002). 
Reactions to the Governors series of allegations were swift and prompt. First was that of Ife community, where "the community spokesman, Prince Olakunle Aderemi, who addressed a press conference at Ife City Hall, on Tuesday, and assisted by Barrister Pade Adewuyi, described as untrue Akande's security report to President Obasanjo over alleged "indefensible contract matters" (Ologbondiyan, 2002). Following this was the reaction of Chief Funmilola Olorunnisola, the press secretary to the imperial majesty, Oba Okunade Sijuwade. According to Chief Funmilola Olorunnisola, "ordinarily, Kabiyesi would have wished to refrain from making any public statement on the matter preferring to stick to a meditative role outside the glare of publicity of any kind. However, the regularity and persistence of the "accusing finger" being pointed at the Ooni of Ife informed the need for reaction. Kabiyesi would want it to be made clear that he is not in any way directly or indirectly involved with the contract “worth $\$ 300$ million” with “Osun State Government”. The press statement went on to say that "Kabiyesi considers both of them" that is Chief Bisi Akande and Otunba Iyiola Omisore "as prominent sons of Osun State who should work together in the interest of the teaming masses of the state (Ologbondiyan, 2002)”.

At this point the situation had gotten messier as the two combatants in power struggle, joined by the press, tried to drag his Imperial Majesty into the crisis and possibly take side with any of them. There was no way the Imperial Majesty could have done this given the fact that parties in dispute are all related to the monarch in different and profound ways. Chief Bola Ige, according to Chief Funmilola Olorunnisola, was “considered as a son, a personal friend, a respected chief of the source; he was also Executive Governor that approved and handed over the staff and other staff instruments of office to him as the Ooni of Ife and had worked closely with him since his days as the Governor of old Oyo State. He was terribly shocked by the accusation that he was covertly supporting a perceived opponent on the ground of the latter's indigene ship of Ife” (Olorunnisola, 2010: p. 189). Chief Ade Bisi Akande on the other hand was Secretary to Oyo State Government when Chief Bola Ige was Governor. Obviously, he signed all the papers related to installation and presentation of staff of office to Ooni of Ife. Otunba Iyiola Omisore is not just ordinary indigene of Ife; he is also a prominent Chief of Ooni of Ife. In the midst of these potentates troika, His Royal Majesty, Ooni of Ife, was caught in a complex web of political intrigues, each courting his support he could not give any one of them without compounding the already over bloated crisis.

By now, the development in the Osun State House of Assembly had begun to move very fast against the Deputy Governor, Otunba Iyiola Omisore. Two Allegations levelled against him and which formed the detailed particulars of the allegations were as follows:

i) BREACH OF OATH OF OFFICE

"That the said Otunba Iyiola Omisore has committed grave violation of the provision of the Constitution relating to the oath of office as Deputy Governor (contained in the Seventh Schedule of 1999 Constitution) of Osun State which he subscribed to on the $29^{\text {th }}$ of May, 1999. By granting an interview reported in the Comet Newspaper of $30^{\text {th }}$ January, 2001 where he divulged the discussions and deliberations of the State Exco in respect of the utilization of the $\$ 1.5$ million water chemical fund”.

ii) CONFLICT OF INTEREST

"That the said Otunba Iyiola Omisore violated the provision of section 1 of the Code of Conduct for public officers as contained in Part 1 of the Fifth Schedule of the 1999 Constitution when he vigorously pursued the said \$1.5 million water chemical fund deal to the High Court of Osun State knowing full well that the deal was illegal and unenforceable in law” (Federal Republic of Nigeria, 2002a, 2002b, 2002c).

Following this, the Honourable Members signed impeachment notice to Deputy Governor IyiolaOmisore. Those who signed the impeachment notice were eighteen in number and they are as follow: (1) (2) Hon. Adisa T.A, (3) Hon. B.O. Hassan, (4) Hon. Femi Popoola, (5) Hon. Komolafe R.O., (6) Hon. AzeezPopoola, (7) Hon. A.A. Tewogbade, (8) Hon. J.O Fakayode, (9) Hon. Babayomi Taiwo, (10) Hon. Gbotoso, (11) Hon. T.A Awotunde, (12) Hon. Lekan Omidiora, (13) Hon. Mrs.OmobonikeTejuoso, (14) Hon. J.A Ajibodu, (15) Hon. Omolaoye Olu. Akintola, (16) Hon. Marooph-deen A. Lawal, (17) Hon. Joshua A. Adediji, (18) Hon. Akin Awoniyi (Federal Republic of Nigeria, 2002a, 2002b, 2002c: p. 4). With these established, the Chief Judge of the state was approached to raise and swear-in impeachment panel that were to investigate allegations levelled against him (Deputy Governor Iyiola Omisore) (Federal Republic of Nigeria, 2002a, 2002b, 2002c: p. 4). Investigative panel members raised included: “(1) Prince Tunde Olashore (Chairman), (2) Alhaji Hamza Hussein, (3) Chief (Mrs.) E.T. Fatoki, (4) Alhaji L.A Olapade, (5) Chief Jameson A. Olowo, (6) Mr. Richard Yoade and (7) Mr. Joshua Oroge” (Federal Republic of Nigeria, 2002a, 2002b, 2002c).

The panel sat for two days but the Deputy Governor refused to appear before the panel although in response 
to the notice, the Deputy Governor wrote a letter to the Panel Chairman declining appearance but the panel had almost ended its sitting before the letter was submitted. In any case, on the $13^{\text {th }}$ December, 2002, the Deputy Governor, Otunba Iyiola Omisore, was removed.

It is important to note here the role of Minority Leader, Hon. Bello Adejare. While he was seen to be very active in the impeachment of Governor Akande by signing as the second person after Hon. Odunayo Olagbaju, his role in the impeachment of Otunba Iyiola Omisore, Deputy Governor, was not overtly clear either in support or against. The inference that can be drawn here is that he appeared to have soft spot for the Deputy Governor. In the 2014 Governorship election in Osun State, he ran as the Deputy Gubernatorial candidate to Senator Iyiola Omisore under Peoples Democratic Party (PDP).

\section{Speaker}

The involvement of the Speaker in the power struggle in the state has two dimensions to it: the press account of his role and the participant observer's account. Analysis of both will be considered separately. Starting with the press account, as the State House of Assembly became factionalised, the Speaker, Dr. Mojeed Alabi, made furtive moves to impeach the Governor and suspend the Deputy Governor (Editorial, 2002). If this had happened, the obvious thing would have been for the Speaker of the House of Assembly to step in as Acting Governor, being the third citizen of the state at that time. This idea of impeaching the Governor and suspending the Deputy was set rolling by the rival party, Peoples Democratic Party (PDP). As the crisis lingered, the state Chairman of PDP, "Alhaji Fatai Akinbade advised the Governor and his Deputy to resign their appointments in the interest of the state" (Icheku, 2002). This might have been the background upon which the Speaker also developed interest in the power struggle to become the Governor. But this is not enough for the Speaker to attempt impeachment of the Governor and his Deputy if he had not being nursing vaulting ambition to be Governor or Deputy Governor.

Developments in other states might also be another impetus that kindled the ambition of the Speaker. Case studies here included Ekiti and Plateau States. In both states, both the Governors and their Deputies were impeached to pave ways for their respective Speakers to become Acting Governors (Nwosu, 2006). To do this, conducting serious legislative matters, particularly impeachment, outside the four walls of the Legislative House, became the order of the day. Otherwise, how does one explain, on one hand, the presence of Speaker and some legislators at Hilton Hotel at Ile-Ife around 1 or 2 A.M.? On the other hand, how does one explain impeachment meeting between a powerful traditional ruler and some legislators' right inside the palace of the powerful monarch? Although all these backfired as the Speaker, Dr. Mojeed Alabi, was also almost impeached. On December 6, 2001, an attempt to impeach the Speaker of the House, Dr. Mojeed Alabi, by one of the factions in the crisis in the state, sparked off violence. During the attempted impeachment, police arrested 48 persons suspected to have perpetrated the violence and subsequently charged them to court (Cover, 2002a, 2002b).

Added to these scenarios were behind the scene actors that people regarded as bedrocks of support for the power strugglers. Chief Bola Ige, Attorney General of the Federation and Minister of Justice, was regarded as the pillar of support for Chief AdeBisi Akande, the Governor, while Ooni of Ife and Alhaji Abubakar Atiku (purveyor of financial assistance) were regarded as the backbones of Otunba Iyiola Omisore, Deputy Governor (Owolabi, 2003). If the Speaker, Dr. Alabi, had one, it was not visible as identities of those who wanted him Governor by muting the idea of impeaching the Governor and suspending the Deputy Governor was not clear. Other than the insinuation that he was hidden in one of the rooms at the Hilton hotel at Ile-Ife, where the Deputy Governors supporters were plotting, there was no other concrete evidence of his having a powerful backer. The combatants, Governor and the Deputy, paid supreme prices to the violence. They both lost their powerful supporters. While the Governor lost his strongest backer and ally, Chief Bola Ige, as well as AD party Chairman in Ife East, Otunba Iyiola Omisore, the then Deputy Governor, only lost his most important supporter and protégé, Odunayo Olagbaju.

The Speaker, Dr. Mojeed Alabi, lost his Deputy Speaker and Chief Whip to kidnappers while he himself was said to have collapsed when manhandled by the police who stormed the Assembly while trying to stop the impeachment trial of the Governor. As a shrewd politician and lawyer, he was extremely careful in the sensitive office he occupied as Speaker. As the head of Osun State Legislature, he is empowered by the Constitution to initiate impeachment proceeding against the Governor and Deputy Governor upon found guilty of gross misconduct. Thus, while the Governor had awesome executive power he could deploy in such titanic battle, he, the Speaker had handsome legislative power he could also deploy. Only the Deputy Governor had neither of the two 
powers and so the most weaklings—-toothless bull dog—of the three combatants, in spite of his position as the number two citizen of the state. In other words, theoretically, the Deputy Governor is superior to the Speaker, but pragmatically, the Speaker is superior to the Deputy Governor. It should be explained as well that the executive power of the Governor had limitations with regard to enforcement of laws and policies. The coercive apparatus such as the Police, State Security Services (SSS) and the Army are controlled by the PDP controlled Federal Government. In some cases, when the Governor gives directive to the Commissioner of Police, such directives are often overridden by the Presidency. For instance, when Governor Chris Ngige of Anambra State could not be impeached by the State's House of Assembly, a civilian coup, engineered by the police kidnapped him. Public and international outcry forced the police to return him to where they kidnapped him. This and many other issues were responsible for the clamouring for State police by the State Governments. In Nigeria, unlike advanced countries, policing matter is under exclusive list of the Federal government; a situation that runs counter to what obtains during colonial period. During the colonial period, Local governments even had police of their own (Olasupo, 2011).

The role of the police in the impeachment crisis in Osun-State is also worth mentioning; this is because the two executive combatants in the struggle for power had no confidence in the police. While AD dragged the Inspector-General of Police, Musiliu Smith, to Court, supporters of the Deputy Governor also issued a threat to Osun-State Commissioner of Police and the Inspector-General of Police respectively to investigate his allegation that Governor wanted to assassinate him. The Deputy Governor provided graphic details of Police involvement in the impeachment crisis thus: "The I.G. is in the picture of some of the crisis in Osun-State. We reported on the $8^{\text {th }}$ of February, 2001 of an attempt to murder me through poison. If the I.G. does not move to solve the problem on time or he tries to conceal information or he refuses to do his job, there will be no peace. So I believe the problem in Osun State as it is now, is that of the police I.G. He should come out specifically to tell the nation how far the police have gone in investigating my allegation. Until the police resolve this problem, the crisis will never be resolved and the state will never know peace” (Icheku, 2002).

In any case, in the battle between the then Osun State Governor and his Deputy, the Speaker was seen as the beautiful bride to the two competing suitors. The beautiful bride was initially swinging between the two suitors until he finally decided to go with the most resourceful and the highest bidder. When the Deputy Governor realized that he had none of these powers and had neither the support of the Party, Alliance of Democracy (AD) and that of the Afenifere (Yoruba socio-political group), he sought for external assistance from the rival party (PDP) — not from its state chapter alone but also the national one. But, given the political sophistication of this state, any attempt to adopt Ngige type of impeachment or coup would have engendered untoward consequence for the state in particular and the country in general.

From the participant observer account, I had opportunity of meeting one of the aides of the Speaker who incidentally is an academic colleague in the same institution with me. I also had opportunity of meeting with the Speaker himself, long after he had left office. My interaction with both proved most of the press accounts and analysis above false. One, the presence of the Speaker, Dr. Mojeed Alabi, at the Hilton Hotel in Ile-Ife had nothing to do with the plotters. It was mere coincidence that he was there at that time, at the invitation of his friend who is the manager of the hotel. He was not even in the midst of the plotter because he was in a separate room in the Hotel. That he was there, in the Hotel, at about 2 A.M. was also faulted because it was during Ramadan Festival and as a devoted Muslim he must have been at his home getting prepared for the next fasting day. Above all, it was found that at 8 P.M. on that day he (the Speaker) phoned Chief Bola Ige. All these were verified by police who initially arrested and detained him. His exoneration was therefore based on the fact that none of these press allegations could be sustained. However it is important to note that because of the critical position of his office in impeachment affairs, his loyalty and support would be a must to all the power strugglers and therefore those who could not get his support, no matter how transparent he was, would want to smear him. My interaction with the Speaker, Dr. Alabi, further revealed that he was not once impeached although several attempts at impeaching him were made. But if several attempts were made at impeaching him without success then it means there is something disgusting with him for which severally Honourable members ceaselessly wanted to remove him. This is evidence, even if tangential, proved that the Speaker was also involved in the power struggle with the two - the Governor and his Deputy.

Under Peoples Democratic Party that came to power in 2007, the two terms tenure of Speaker Hon. Adejare Bello could not be said to be completely free of crisis and impeachment but not as profound as that of Speaker Mojeed Alabi. In the course of the inauguration of Osun State House of Assembly in 2007, four legislators 
members belonging to Action Congress (AC) that metamorphose from Alliance for Democracy (AD), were arrested ostensibly for destruction of properties in the general elections that did not favour them (The Nation, 2007). For this, the remaining colleagues of AC legislators in the House boycotted the inauguration of the new Speaker and the new House of Assembly (ThisDay, 2007).

Following this were divisive issues of in-house elections of clerk, whip and majority leader, conducted by PDP legislators in the absence of their rival AC legislators. AC legislators had alleged that the elections of these officers were done in their absence during their boycott of the Assembly proceedings as a result of arrest of their four colleagues; subsequently, they went to court. Meanwhile, they had started making call for the impeachment of Speaker Adejare Bello and his Deputy although this fell on deaf ears (Osun Mail, 2007). So, as there was no serious impeachment threat against Governor Oyinlola, so were there none against Deputy Governor and Speaker Adejare Bello who were all PDP Executives and Speaker.

\section{Observation}

Series of observations are made in this paper: one, the crisis in Osun State between 1999 and 2003 was clearly intra party and intra governmental affairs that provided the rival parties opportunity to fish in it. Two, it is clearly evident that neither power struggle nor impeachment is a proper means of attaining power. Three, it also shows that attaining power by any of these means or both bread violence not only among the ruling class but the electorates as well. This is evident by the fact that the three most powerful citizens of the state (Osun) between 1999 and 2003 lost one person or the other. While the Governor, Chief Bisi Akande, lost his strongest backer, Chief Bola Ige, and a Local Government Party Chairman in Ife East Local Government Council, the Deputy Governor, Otunba Iyiola Omisore lost his staunchest supporter and ally, Hon. Odunayo Olagbaju. As for the Speaker, Dr. Mojeed Alabi, his Deputy Speaker and Chief Whip were kidnapped (Notice of allegation, 1999). He, the Speaker, Dr. Alabi, also almost lost his life as he was said to have collapsed in the House of Assembly when security officials manhandled him in the course of trying to impeach the Governor. Fourthly, the question of traditional rulers in modern governance in the country needs revisiting. It is an illusion of immense propensity for anybody to think they (traditional rulers) are irrelevant in modern governance in Nigeria, given their immense political, financial and primordial influences in both local and national politics; particularly those, Ayoade refers to as "over mighty subjects" that local, state and federal administrators constantly avoided (Ayoade, 1995). Ultimately, this crisis, in part, contributed immensely to the loss of Osun State to rival party (PDP) in the 2003 general elections.

After the 2003 general elections, the Minority leader in the preceding administration, Hon. Adejare Bello, became the Speaker while the former Deputy Governor emerged as Senator, both under PDP administrations at Local, State and Federal levels. It is interesting to observe that the tenures of the Speaker Bello witnessed rancour free period. A lot of factors were accountable for this peaceful tenures of Speaker Adejare Bello. The first important sterling attribute of Barrister Adejare Bello, as the Speaker of Osun State House of Assembly for two terms, was accommodation and felicitation with opposition members. He was on hand at a special sitting in honour of departed Afenifere leader, Chief Abraham Adesanya in 2008. When the present Action Congress of Nigeria (CAN) leader and former AD Governor, Chief AdeBisi Akande was also marking his 70th birthday in 2009 he was also promptly present at his birthday ceremony. What is more, against insinuation that AC members of the House of Assembly were uncooperative with the ruling party, PDP, Speaker Adejare Bello promptly came to the rescue of his fellow rival legislators. According to him "AC House members are not elements of delay in decision making and states progress". Secondly is the fact that among the Governor, Deputy Governor and the Speaker in the last administration in the state, there was none with identifiable inordinate ambition. The then Governor, Olagunsoye Oyinlola's ambition was to be a Senator before he was dragged into governorship race. The Deputy, Erelu Obada, another perfect, gentle and apolitical woman, was made the Deputy. To complete these gentilities, a menthol Speaker was sought for and found in Honourable Adejare Bello who happened to be an equally, if not more, perfect gentleman rarely heard or seen outside his legislative duties and chamber? Thus, the last set of the executive and legislature, while not a complete perfect one, provided effective counterweight to its preceding constantly bickering and bloody one.

\section{Conclusion}

The conclusion that can be drawn from all these is that due process of attaining power is the only appropriate means of attaining power. While impeachment is a necessary constitutional process of removing criminal Chief 
Executives, due process for doing so must be followed as against subversion of it by conducting the business of the House outside its chamber. It should also be noted that there is nothing wrong in having ambition. In fact, a man or woman without ambition is as good as being dead; what is wrong, unacceptable and likely to cause breach of public peace is inordinate ambition.

\section{References}

Adeyemo, W. (2002). Endangered Species: Lagos State Deputy Governor, Kofoworola Bucknor-Akerele, Resigns Her Position as Some of Her Colleagues Face Testing Time in Their States. Tell of December 30, 48.

Aja, U. (2001). A Tale of Two Speakers. Source of December 24, 29.

Ajayi, S. (2001). Osun: A State in Unending Crisis. ThisDay of December 25, 7.

Akinsanya, A. A. (2005). The Judiciary and Interpretation of Aspects of the 1979 Nigerian Constitution 1979-1983. In: A. A. Akinsanya, \& J. A. Ayoade (Eds.), Readings in Nigerian Government and Politics (p. 177). Ijebu-Ode: Gratia Associates International.

Ayoade, J. A. A. (1995). The Development of Democratic Local Government in Nigeria. Local Government in Nigeria and the United States: Learning from Comparison (p. 25). Ile-Ife: Local Government Publication Series, Department of Local Government Studies, Faculty of Administration, ObafemiAwolowo University.

Babarinsa, D. (2002). How Deputy Governor Omisore’s Men Harassed Igeat Ife. Tell of January 7, 28.

Cover (2002a). Ige: The Star Suspect's Story. The News of January 28, 26.

Cover (2002b). Impeachment: Nigeria May Break up—Governor Akande. Tell of September 23, 28.

Daily Independence (2005). Power Struggle in the State and Constituency Project. Daily Independence of November 30, xii.

Editorial, T. (2002). Osun: Demonstration of Craziness. Tempo of January 3, 8.

Federal Republic of Nigeria (2000). Osun State House of Assembly, Second Assembly, 2nd Session, No 046, Votes and Proceedings, 6 November.

Federal Republic of Nigeria (2002a). Osun State House of Assembly. Second Assembly, 4th Session, No. 053, Votes and Proceedings. 12 November, 4.

Federal Republic of Nigeria (2002b). Osun State House of Assembly. Second Assembly, 4th Session, No. 054, Votes and Proceedings. Wednesday, 20 November, 1-2.

Federal Republic of Nigeria (2002c). Osun State House of Assembly. Second Assembly, 4th Session No. 055, Votes and Proceedings. 13 December, 2. See also Verbatim Evidence of Witnesses at the Proceedings at the Panel Investigating the Allegation against OunbaIyiola Omisore, Deputy Governor of Osun State, 28-29 December, 1.

Icheku, T. (2002). Echoes of Anarchy from Osun. ThisDay, 19 January 2002, 45.

Ikhariale, M. (2002). The Impeachment Myth versus the Nigerian Reality. http://www.nigerdeltacongress.Com/iarticles/Impeachment_myth_versus_the_nige.htm

Iyinbo, O. (2007). Nigeria’s Impeachment Saga: Democracy on the Legislature’s Butcher Block. http://findarticles.Com/p/articles/mi-m5QWD/is_1_5/ai_n25001269

Jason, P. (2006). The Weighty Side of Impeachment. Vanguard Newspaper, 31 October, 5.

Nwosu, S. (2006). Winners and Losers Emergency Rule in Ekiti State. Saturday, 21 October 2006.

Okenyi, D. (2000). Invasion of the Osun State House of Assembly. DTHA/TD.6/VOL.iv/118, 9 November 2000.

Olasupo, F. A. (2011). Police Rebellion and Coup D’Etat in West Africa: The Cases of Senegal and Nigeria. OIDA International Journal of Sustainable Development, 2, 59-68. http://ssrn.com/abstract=1974122

Olasupo, F. A. (2014). Voice of Jacob Hand of Esau: Appraising the Role of Chief Executives and Party Leaders in Impeachment Processes in Nigeria. University of Political Science and Law, Beijing Law Review, 5, 8.

Ologbondiyan, K. (2002). A State and Its Web of Intrigues. ThisDay, 19 January 2002, 45.

Olorunnisola, F. (2010). From the Tube to Royalty (My Own Story) (p. 188).

Omololu, F. (2007). Judicial Review of Impeachment Procedure: Implication for Democratic Stability in Nigeria. The Annual Meeting of the International Society of Political Psychology, Classical Chinese Garden, Portland.

Osun Mail (2007). AC Wants Speaker \& Deputy Removed. Osun Mail, 1 November 2007.

Owolabi, Y. (2002a). Ige Haunts Omisore. Tell, 30 December 2002, 41.

Owolabi, Y. (2002b). Murder in the Spring. Tell, 7 January 2002, 2.

Owolabi, Y. (2003). Omisore and the Game of His Godfathers. Tell, 17 March 2003, 31. 
The Guardian (2005). Forces against Oyinlola Ambition in Osun State. The Guardian, 1 April 2005, 1.

The Nation (2007). Osun AC Lawmakers Sue Speaker, Seeking Nullification of OSHA Principal Officers’ Election. The Nation, 23 August 2007, 5.

ThisDay (2007). Like Osun, Like Ekiti. ThisDay, 1 July 2007, 112-113. 
Scientific Research Publishing (SCIRP) is one of the largest Open Access journal publishers. It is currently publishing more than 200 open access, online, peer-reviewed journals covering a wide range of academic disciplines. SCIRP serves the worldwide academic communities and contributes to the progress and application of science with its publication.

Other selected journals from SCIRP are listed as below. Submit your manuscript to us via either submit@scirp.org or Online Submission Portal.
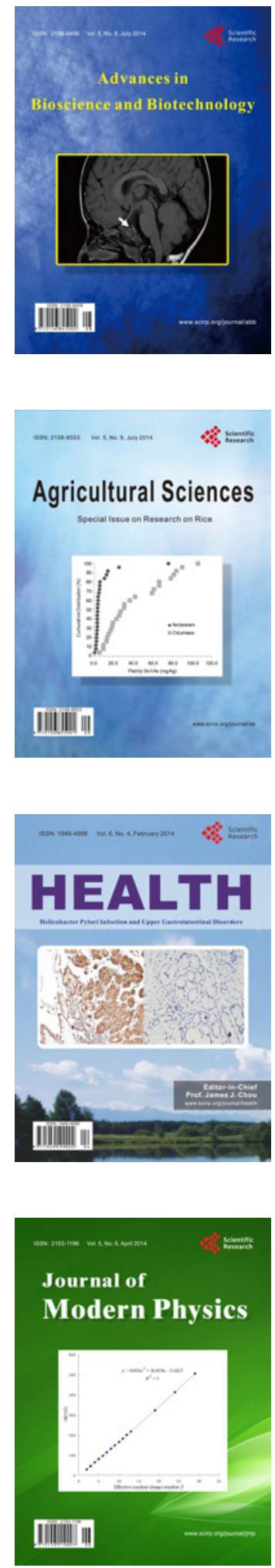
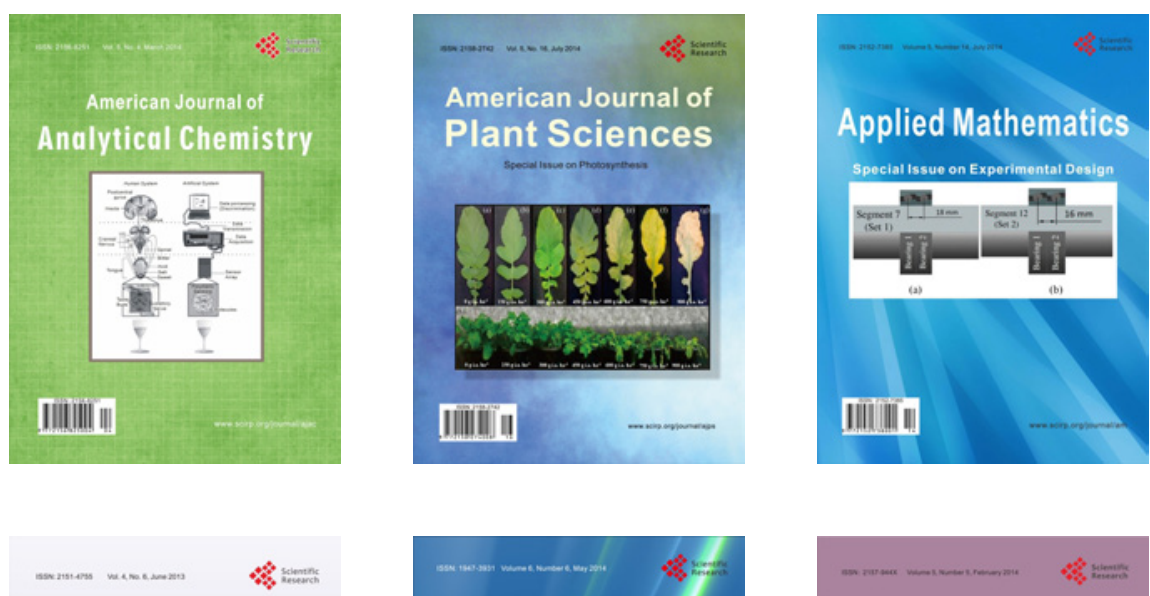

Creative Education
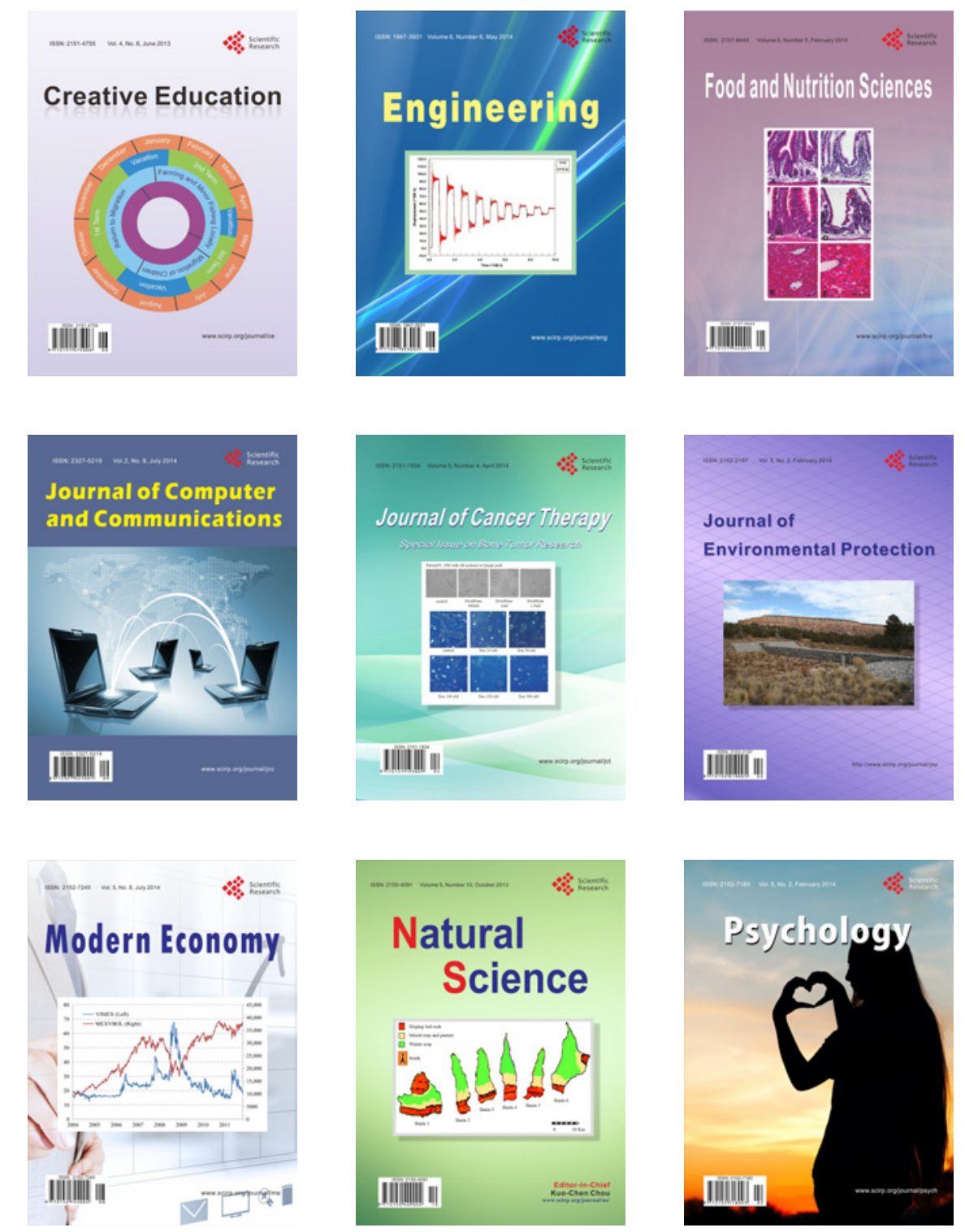